\title{
Free-living amoebae and their associated bacteria in Austrian cooling towers: a 1-year routine screening
}

\author{
Ute Scheikl $^{1} \cdot$ Han-Fei Tsao ${ }^{2}$ - Matthias Horn ${ }^{2}$ Alexander Indra ${ }^{3}$ • \\ Julia Walochnik ${ }^{1}$
}

Received: 22 April 2016/Accepted: 27 April 2016/Published online: 14 May 2016

(C) The Author(s) 2016. This article is published with open access at Springerlink.com

\begin{abstract}
Free-living amoebae (FLA) are widely spread in the environment and known to cause rare but often serious infections. Besides this, FLA may serve as vehicles for bacterial pathogens. In particular, Legionella pneumophila is known to replicate within FLA thereby also gaining enhanced infectivity. Cooling towers have been the source of outbreaks of Legionnaires' disease in the past and are thus usually screened for legionellae on a routine basis, not considering, however, FLA and their vehicle function. The aim of this study was to incorporate a screening system for host amoebae into a Legionella routine screening. A new real-time PCRbased screening system for various groups of FLA was established. Three cooling towers were screened every 2 weeks over the period of 1 year for FLA and Legionella spp., by culture and molecular methods in parallel. Altogether, $83.3 \%$ of the cooling tower samples were positive for FLA, Acanthamoeba being the dominating genus. Interestingly, $69.7 \%$ of the cooling tower samples were not suitable for the standard Legionella screening due to their high organic burden. In the remaining samples, positivity for Legionella spp. was $25 \%$ by culture, but overall positivity was $50 \%$ by molecular methods. Several amoebal isolates revealed intracellular bacteria.
\end{abstract}

Julia Walochnik

julia.walochnik@meduniwien.ac.at

1 Institute of Specific Prophylaxis and Tropical Medicine, Medical University of Vienna, Vienna, Austria

2 Department of Microbiology and Ecosystem Science, Division of Microbial Ecology, University of Vienna, Vienna, Austria

3 Department of Mycobacteriology and Clinical Molecular Biology, AGES, Vienna, Austria
Keywords Free-living amoebae $\cdot$ Screening $\cdot$ Real-time PCR $\cdot$ Acanthamoeba $\cdot$ Legionella $\cdot$ Cooling towers

\section{Introduction}

Free-living amoebae (FLA) have a worldwide distribution and are found in various natural habitats like soil, freshwater and seawater (Smirnov and Brown 2004; Berk et al. 2006; Geisen et al. 2014). Additionally, they can colonize engineered water facilities, including water treatment plants, air conditioning units, plumbing systems, drinking water networks and cooling towers (Delafont et al. 2013; Retana-Moreira et al. 2014; Canals et al. 2015). In all of these habitats, FLA play an important role as vehicles of replication and dispersal for bacteria (Cirillo et al. 1997; La Scola and Raoult 2001; WinieckaKrusnell and Linder 2001; Greub and Raoult 2004; Siddiqui and Khan 2012). The extremely resilient genus Acanthamoeba is a particularly well-suited host for a long list of bacteria, including Legionella pneumophila, the causative agent of Legionnaires' disease, a severe pneumonia (Rowbotham 1980). In the amoebae, the legionellae are protected from changes in $\mathrm{pH}$ and temperature and from disinfection (Wadowsky et al. 1985; Ohno et al. 2003; Hwang et al. 2006; Dupuy et al. 2011; Cervero-Aragó et al. 2014). Moreover, passage through amoebae seems to enhance their virulence and to resuscitate viable but non-culturable (VBNC) legionellae (Cirillo et al. 1999; Steinert et al. 1997; García et al. 2007). Under environmental stress, legionellae can enter the VBNC state, a physiological dormant state, in which they cannot be detected by standard cultivation techniques (Hussong et al. 1987; Robertson et al. 2014).

Man-made habitats like open cooling towers can disseminate legionellae via aerosols (Walser et al. 2014). These aerosols can be distributed over long distances up to $6 \mathrm{~km}$ (Addiss 
et al. 1989). Cooling towers of large public buildings pose a particular risk and have been reported as sources of community-acquired and nosocomial outbreaks of Legionnaires' disease (Nguyen et al. 2006; Hugosson et al. 2007; Sala Ferré et al. 2009; Freudenmann et al. 2011; Buse et al. 2012). An example for such an incidence in Austria was reported in 2007 (Wewalka 2013), when the cooling towers of a hospital were the source of a Legionella outbreak with 16 cases of legionellosis, including three lethal ones. The cases occurred not only in the hospital itself but also in its surroundings. Until now, legislation in Austria does neither require the registration of wet cooling systems nor are regular microbiological monitoring or standard disinfection mandatory. Most public cooling towers are, however, screened on a routine basis by the respective operating company. Thus, a project was initiated to incorporate a screening system for host amoebae into a routine screening program for legionellae. A particular aim of this study was to synchronously assess the diversity of FLA relevant as bacterial hosts and to also investigate all amoebal isolates for intracellular bacteria. Thus, a rapid and reliable screening system for the detection and synchronous differentiation of the host amoebae was established.

\section{Materials and methods}

\section{Sample collection and processing}

The study included three open cooling towers that are under permanent observation for legionellae and under regular albeit not standardized disinfection. The routine screening in operation also includes Pseudomonas aeruginosa and total bacteria. Two of the cooling towers were hospital cooling towers, belonging to two different hospitals, one in the centre of Vienna (CT-Hospital 1) and the other one in the periphery of Vienna (CT-Hospital 2). Cooling towers of Hospital 1 had been the source of the Legionella outbreak in 2007 and since then had been dismantled and renewed. The third cooling tower (CTCompany) was from a complex of company buildings, located in the same district as CT-Hospital 1 and comprising several large office buildings with bureaus, shops, restaurants, a kindergarten and also an outpatient clinic. Moreover, 12 tap waters (Tap) from various sites were sampled over the same period of time for comparison, including one sample from a previously Legionella-contaminated shower head in another hospital in Vienna. During the study period of 1 year, water samples were obtained every 14 days, corresponding to the recommendations for routine Legionella screening. CTCompany was not sampled between November 2013 and March 2014 as the system was not in operation. Currently, there is no standardized disinfection protocol for cooling towers in Austria. The cooling towers included in this study are disinfected over a dosimeter with chlorine and bromine- based oxidative biocides. During the study, CT-Hospital 1 was disinfected three times a week (OptiDOS 39D ${ }^{\circledR}$, OptiDOS DSB $^{\circledR}$ ), CT-Hospital 2 every 18 h (Waterdos CLD 08 ${ }^{\circledR}$ ) and CT-Company every 4 days (Waterdos CIT48 ${ }^{\circledR}$ ). As we have shown in a previous study that amoebae re-colonize waters rapidly after disinfection (Scheikl et al. 2014) and to have stringent conditions for the frequency of occurrence of amoebae, samples were always obtained within $24 \mathrm{~h}$ after disinfection. Water temperatures from all sites were recorded throughout the study.

Sampling procedure and evaluation strictly followed the new requirements for evaporative re-cooling plants (ÖNORM B 5020:2013 Austrian Standards Institute 2013). From each sampling site, $3 \mathrm{~L}$ of water was collected in sterile plastic bottles, stored at $4{ }^{\circ} \mathrm{C}$ and processed within $48 \mathrm{~h}$. For direct DNA isolation from water samples, $2 \mathrm{~L}$ was filtered and DNA was extracted from cellulose nitrate filters using the $\mathrm{MO}$ BIO PowerWater ${ }^{\circledR}$ DNA Isolation Kit (MO BIO Laboratories Inc., Carlsbad, CA). The isolated DNA was stored at $-20^{\circ} \mathrm{C}$ until use for molecular analyses.

\section{Screening for FLA}

For the detection of Acanthamoeba spp., a real-time PCR assay (Qvarnstrom et al. 2006) was adapted, using the primers AcantF900 5'-CCCAGATCGTTTACCGTGAA-3', AcantR1100 5'-TAAATATTAATGCCCCCAACTATCC-3' and the Cy5-labelled probe AcantP1000 5'-Cy5CTGCCACCGAATACATTAGCATGG-BHQ3-3' and amplifying fragments of 170 to $230 \mathrm{bp}$, depending on the genotype. For design of the primers and probe for the detection of Vahlkampfiidae, particularly Naegleria spp., we retrieved partial or full length 18S rDNA sequences from GenBank (NCBI, National Center for Biotechnology Information) and included them in multiple sequence alignments. Sequences of Naegleria jamiesoni, Naegleria andersoni, Naegleria clarki, Naegleria andersoni, Naegleria fultoni, Naegleria pagei, Naegleria australiensis, Naegleria lovaniensis, Naegleria fowleri, several unidentified Naegleria spp. strains and additionally, 13 sequences from other vahlkampfiids including Paravahlkampfia, Vahlkampfia, Singhamoeba, Willaertia and Tetramitus were evaluated and compared for conserved and variable regions resulting in the new primers VahlNaegF 5'-GTATAGTCGCAAGACCGAAAC-3', VahlNaegR 5'CAAGACAGATCACTCCACGA-3' and the Cy5-labelled probe VahlNaegP 5'-Cy5-GAAAGGCACCACCAG GAGTG-BHQ2-3', amplifying a 190-200-bp fragment of the $18 \mathrm{~S}$ rDNA. The same procedure was followed for the design of the primers and probe for the detection of Vermamoeba vermiformis, namely VermHartF 5'TAACGATTGGAGGGCAAGTC-3', VermHartR 5'ACGCCTGCTTTGAACACTCT-3' and the HEX-labelled probe VermHartP 5'-HEX-TGGGGAATCAACC 
GCTAGGA-BHQ1-3' with an amplicon of approximately $240 \mathrm{bp}$ in length. The specificity of all primers and probes was evaluated with Primer3Plus, BLAST Nucleotide search and multiple alignments with other amoebal genera. Moreover, PCR test runs were performed with several reference strains, to check specificity and sensitivity. The PCRs were duplexed with an Exogenous Internal Positive Control (IPC) to distinguish true target negatives from PCR inhibition (Behets et al. 2007). Real-time PCRs were performed in a final reaction volume of $20 \mu \mathrm{l}$, containing $1 \times$ TaqMan ${ }^{\circledR}$ Fast Universal PCR Mastermix (Applied Biosystems, USA), forward primer $(0.9 \mu \mathrm{M})$, reverse primer $(0.9 \mu \mathrm{M})$, probe $(0.25 \mu \mathrm{M}), 1 \times$ Exo IPC Mix, 1× Exo IPC, $3 \mu \mathrm{l}$ DNA and sterile $\mathrm{H}_{2} \mathrm{O}$ (for DNA analysis, Carl Roth, Germany). PCRs with no IPC signal were repeated with tenfold diluted DNA. Real-time PCRs were performed in a Light Cycler $^{\circledR}$ LC 480 Instrument (Roche, Germany) with an initial activation step at $95^{\circ} \mathrm{C}$ for $10 \mathrm{~min}$ followed by 45 cycles of $95^{\circ} \mathrm{C}$ for $15 \mathrm{~s}$ and $60{ }^{\circ} \mathrm{C}$ for $60 \mathrm{~s}$. Fluorescence was measured at the end of the $60{ }^{\circ} \mathrm{C}$ anneal/extend step. Samples with a $\mathrm{Ct}$ (threshold cycle) value below 40 were considered to be positive. The cell detection limit for Acanthamoeba and Vahlkampfiidae was below one cell whereas the detection limit for $V$. vermiformis was about three cells. Data were analysed with the LightCycler ${ }^{\circledR}$ 480 Software (version 1.5) and calculated using the secondderivate maximum algorithm.

\section{Reference strains}

For the establishment of the real-time PCR assays and as controls, we used amoeba reference strains from our culture collection, namely Acanthamoeba polyphaga strain 4CL, genotype T4 (ATCC PRA-107 ${ }^{\text {TM}}$; Walochnik et al. 2000), Acanthamoeba castellanii strain 1BU, genotype T4 (ATCC PRA-105 ${ }^{\mathrm{TM}}$ ), $V$. vermiformis strain 1282-2 (isolated from a contact lens case, 2010), Hartmannella cantabrigiensis strain Hc (Walochnik et al. 1999), Naegleria lovaniensis strain $12 \mathrm{~N}$ (veterinary faeces sample, 2005) and Naegleria gruberi strain 40N (GenBank accession no. AF114439). From each reference strain DNA was extracted from tenfold dilution series $\left(10^{5}\right.$ cells $/ \mathrm{ml}$ to $\left.1 \mathrm{cell} / \mathrm{ml}\right)$, so that the highest diluted sample contained less than one amoebal cell per $20 \mu \mathrm{l}$ reaction mix.

\section{FLA culture and identification}

For isolation of FLA, $250 \mathrm{ml}$ of well-mixed water samples was vacuum-filtered through a cellulose nitrate filter with $0.45 \mu \mathrm{m}$ pore size (area $12.5 \mathrm{~cm}^{2}$, Sartorius, Germany). After filtration, each filter was placed up-side down onto a NN (non-nutrient) agar plate covered with $100 \mu$ of a 48-hold culture of Escherichia coli in brain-heart-infusion-broth (BHI) (Sigma-Aldrich, Vienna, Austria). In order to give the amoebae more opportunities to migrate into the bacterial lawn, the filters were cut into two pieces before placing them onto the plates. The plates were sealed with Parafilm ${ }^{\circledR}$ and stored at room temperature for up to 4 weeks, investigating them daily for amoebal growth by inverted phase contrast microscopy (Nikon TMS). Detected FLA were transferred to fresh E. coli-coated NN plates using a sterile inoculation loop. All amoebal isolates were cloned by sub-culturing to generate pure cultures for subsequent DNA isolation. Morphological identification was accomplished by inverted phase contrast and bright field microscopy (Nikon Eclipse E800) using the identification keys of Page (Page 1991) and Smirnov (Smirnov et al. 2011). Trophozoites from clonal cultures were harvested with cotton swabs and re-suspended in $15 \mathrm{ml}$ centrifuge tubes filled with $5 \mathrm{ml} 0.9 \%$ sodium chloride $(\mathrm{NaCl})$. The samples were centrifuged for $10 \mathrm{~min}$ at $800 \times \mathrm{g}$, the supernatants were discarded and the pellets were re-suspended in $200 \mu \mathrm{l} 0.9 \% \mathrm{NaCl}$. Total genomic DNA was extracted from the cells using the QIAmp ${ }^{\circledR}$ DNA Mini Kit (QIAGEN, Hilden, Germany). Genotyping of Acanthamoeba isolates was performed by amplifying and sequencing a 385-450-bp (depending on the genotype) long fragment of the Acanthamoeba-specific amplimer ASA.S1 located in the 18S rRNA gene using the newly designed primer AcF1 5'TGCCACCGAATACATTAGCAT-3' and AcR 1 5'ACAAGCTGCTAGGGGAGTCA-3', modified from the JDP2 primer from Schroeder et al. (2001). PCRs were run with 1, 3 and $6 \mu$ whole cell DNA in a total reaction volume of $50 \mu \mathrm{l}$ for each sample under the following conditions: 15 min pre-heating at $95^{\circ} \mathrm{C}$, followed by 35 cycles at $95^{\circ} \mathrm{C}$ for $1 \mathrm{~min}, 60{ }^{\circ} \mathrm{C}$ for $2 \mathrm{~min}, 72{ }^{\circ} \mathrm{C}$ for $3 \mathrm{~min}$ and a final extension for $7 \mathrm{~min}$ at $72{ }^{\circ} \mathrm{C}$. An ASA.S1 amplicon clone of a T4 genotype strain was used as a positive control. Acanthamoeba genotypes were assessed with the model assumption of a $<5 \%$ sequence dissimilarity within one genotype (Gast et al. 1996). DNA extracted from other amoebae isolated by culture was amplified and sequenced using universal eukaryotic primers binding in the $18 \mathrm{~S}$ rRNA gene, namely the modified primers SSU1 5'-CGACTGGTTGATC CTGCCAGTAG3' and SSU2 5'-TCCTGATCCTTCTGC AGGTTCAC-3' (Gast et al. 1994) and P1fw 5'-CAAGTCT GGTGCCAGCAGC-3'，P1rev 5'-GCTGCTGGCAC CAGACTTG-3', P2fw 5'-GATCAGA TACCGTCGTAGTC3', P2rev 5'-GACTACG ACGGTATCTGATC-3', P3fw 5'CAGGTCTGT GATGCCCTTAG-3' and P3rev 5'CTAAGGGCA TCACAGACCTG-3' (Walochnik et al. 2004). PCR was performed with 1,3 and $6 \mu$ l of whole cell DNA in $50 \mu$ reaction volume running a standard amplification program $\left(35\right.$ cycles; $95{ }^{\circ} \mathrm{C}$ for $1 \mathrm{~min}, 52{ }^{\circ} \mathrm{C}$ for $2 \mathrm{~min}$, $72{ }^{\circ} \mathrm{C}$ for $3 \mathrm{~min}$ ). Amplified DNA was detected by gel electrophoresis on a $2 \%$ agarose gel and visualized with GelRed $^{\text {TM }}$ (BIOTREND, Germany). Gel bands were extracted with the GFX PCR DNA and Gel Band Purification Kit (GE Healthcare, UK) and directly sequenced in both directions 
with the ABI PRISM ${ }^{\circledR}$ BigDye sequencing kit and an ABI PRISM $310^{\circledR}$ automated sequencer (PE Applied Biosystems, Germany). All sequences obtained were compared to sequences from GenBank with the NCBI Nucleotide BLAST search and aligned with sequences of highest similarity using ClustalX (Thompson et al. 1997) or CLC Main Workbench (CLC bio, QIAGEN). Multiple alignments were processed with the GeneDoc sequence editor (Nicholas et al. 1997).

\section{Screening for intracellular bacteria}

All isolates were screened for intracellular bacteria. Endosymbionts were demonstrated by FISH (fluorescence in situ hybridization) using the probe EUK516 (5'ACCAGACTTGCCCTCC -3'), detecting most Eukaryotes, a mix of bacterial probes, namely EUB338 I-III (5'GCTGCC TCCCGTAGGAGT-3', 5'-GCAGCCAC CCGTAGGTGT-3', 5'-GCTGCCACCCGTAGGTGT-3'; Amann et al. 1990; Daims et al. 1999) and the negative control probe NONEUB (5'-ACTCCTAC GGGAGGCAGC-3'). Amplification and identification were performed by $16 \mathrm{~S}$ rRNA gene sequencing using the forward primer 27F (5'AGAGTTTGATCCTGGCTCAG-3') and reverse primer 1492R (5'-GGTTACCTTGTTACGACTT-3') (Lane 1991).

\section{Routine screening for bacteria}

The bacterial screening was performed according to the respective international regulations. The water samples were analysed for Legionella spp. CFU/100 ml (colony forming units in $100 \mathrm{ml}$ ) after centrifugation and filtration of $100 \mathrm{ml}$ untreated water and after acid treatment, respectively (ISO 11731-2 2004). Legionella species were identified by sequencing the mip-gene and L. pneumophila was serotyped according to the EWGLI- (European Working Group for Legionella Infections 2011) criteria. If despite acid treatment organic burden prohibited filtration of $100 \mathrm{ml}$, smaller volumes, i.e. $1-10 \mathrm{ml}$, were used, as is standard procedure. For comparison, a random set of 28 cooling tower samples were also analysed by amplicon sequencing for the presence of operational taxonomic units (OTUs) classified as members of the genus Legionella.

P. aeruginosa was evaluated in $100 \mathrm{ml}$ of water (ISO $162662008)$ and total heterotrophic bacteria were counted as $\mathrm{CFU}$ in $1 \mathrm{ml}$ at $36^{\circ} \mathrm{C}$ (ISO 62221999 ).

\section{Amplicon sequencing and analysis}

Amplicon sequencing was performed as described in Herbold et al. (2015). The V3 and V4 regions of the bacterial 16S rRNA were amplified with barcoded versions of the primers Bakt_341F (CCTACGGGNGGCWGCAG) and Bakt_805R
(GACTACHVGGGTATCTAATCC) (Herlemann et al. 2011). Each PCR reaction included $1 \times$ DreamTaq Green Buffer (Fermentas, Thermo Fisher Scientific, Vienna, Austria), $2 \mathrm{mM} \mathrm{MgCl}_{2}, 0.2 \mathrm{mM}$ dNTP mix (Fermentas), $0.1 \mathrm{mg} \mathrm{ml}^{-1}$ bovine serum albumin, $1 \mu \mathrm{M}$ of each of the forward and reverse primers, $0.025 \mathrm{U}$ DreamTaq polymerase (Fermentas) and $1 \mu \mathrm{l}$ of template. The PCR was performed with a cycle ratio of 25:10. Clustering into OTUs was performed as described previously (Herbold et al. 2015). Taxonomic classification was carried out using the mothur classify.seqs function (Schloss et al. 2009) and the Silva 1.19 SSU database as reference (Quast et al. 2013). The bootstrap threshold for the taxonomic assignment was set to $80 \%$.

\section{Statistical analysis}

The collected data were analysed with IBM SPSS Statistics, version 19 (SPSS Inc., Chicago, USA). Frequency distributions were compared using chi-square tests or Fisher's exact probability test, as appropriate. Dependent frequencies were compared by McNemar tests. For all analyses, $p$ values below 0.05 were considered significant.

\section{Results}

The two hospital cooling towers showed temperatures between 20 and $30^{\circ} \mathrm{C}$ throughout the entire year, with mean temperatures of above $25^{\circ} \mathrm{C}$. The company cooling tower showed temperatures below $20{ }^{\circ} \mathrm{C}$ at the beginning of the operating time and this cooling tower was not in use during the winter (November to March). The tap water samples had temperatures between 4 and $12{ }^{\circ} \mathrm{C}$.

\section{Screening for FLA relevant as hosts for bacteria}

Altogether, $83.3 \%(55 / 66)$ of the cooling tower samples and $50 \%(6 / 12)$ of the tap water samples were positive for FLA (Table 1). The shower head sample was negative in all three real-time PCR tests (not shown). Acanthamoeba was the most prevalent genus, detected in $71.2 \%$ of all cooling tower samples and in $50 \%$ of the tap water samples (Table 1). In tap water, Acanthamoeba was the only genus of FLA found, while cooling waters also had a high frequency of occurrence of vahlkampfiids ( $57.6 \%$ positive samples). In $45.5 \%$ of all cooling tower samples, Acanthamoeba co-occurred with vahlkampfiids, with the highest numbers of samples being positive for both taxa in CT-Hospital 1 (65.4\%). In comparison, CT-Hospital 2 showed significantly higher frequencies of Acanthamoeba than of Vahlkampfiidae $(p=0.01)$. The genus Vermamoeba always co-occurred with vahlkampfiids (7.6\%) and in $4.5 \%$ of the samples all three groups of FLA were detected simultaneously. 
Table 1 Positivity rates of FLA in cooling towers and tap waters, evaluated by real-time PCR

\begin{tabular}{|c|c|c|c|c|c|c|}
\hline FLA & & $\begin{array}{l}\text { Cooling tower } \\
\text { Hospital } 1\end{array}$ & $\begin{array}{l}\text { Cooling tower } \\
\text { Hospital } 2\end{array}$ & $\begin{array}{l}\text { Cooling tower } \\
\text { Company }\end{array}$ & Tap water & Total \\
\hline Acanthamoeba & $\begin{array}{l}\%^{\mathrm{a}} \\
\text { Number }^{\mathrm{b}}\end{array}$ & $\begin{array}{l}69.2 \% \\
18\end{array}$ & $\begin{array}{l}84.6 \% \\
22\end{array}$ & $\begin{array}{l}52.0 \% \\
7\end{array}$ & $\begin{array}{l}50.0 \% \\
6\end{array}$ & $\begin{array}{l}67.9 \% \\
53\end{array}$ \\
\hline Vahlkampfiidae & $\begin{array}{l}\% \\
\text { Number }\end{array}$ & $\begin{array}{l}84.6 \% \\
22\end{array}$ & $\begin{array}{l}42.3 \% \\
11\end{array}$ & $\begin{array}{l}35.7 \% \\
5\end{array}$ & - & $\begin{array}{l}48.7 \% \\
38\end{array}$ \\
\hline Vermamoeba & $\begin{array}{l}\% \\
\text { Number }\end{array}$ & $\begin{array}{l}11.5 \% \\
3\end{array}$ & $\begin{array}{l}3.8 \% \\
1\end{array}$ & $\begin{array}{l}7.1 \% \\
1\end{array}$ & - & $\begin{array}{l}6.4 \% \\
5\end{array}$ \\
\hline Acanthamoeba + Vahlkampfiidae & $\begin{array}{l}\% \\
\text { Number }\end{array}$ & $\begin{array}{l}65.4 \% \\
17\end{array}$ & $\begin{array}{l}42.3 \% \\
11\end{array}$ & $\begin{array}{l}14.3 \% \\
2\end{array}$ & - & $\begin{array}{l}38.5 \% \\
30\end{array}$ \\
\hline Acanthamoeba + Vahlkampfiidae + Vermamoeba & $\begin{array}{l}\% \\
\text { Number }\end{array}$ & $\begin{array}{l}7.7 \% \\
2\end{array}$ & $\begin{array}{l}3.8 \% \\
1\end{array}$ & - & - & $\begin{array}{l}3.8 \% \\
3\end{array}$ \\
\hline Total & Number & $88.5 \%(23 / 26)$ & $84.6 \%(22 / 26)$ & $71.4 \%(10 / 14)$ & $50.0 \%(6 / 12)$ & $78.2 \%(61 / 78)$ \\
\hline
\end{tabular}

${ }^{\text {a }}$ Relative frequencies of amoeba-positive samples in different sampling sites

${ }^{\mathrm{b}}$ Absolute numbers of positive samples

Altogether, CT-Hospital 1 showed the highest frequency of occurrence of FLA, with $89 \%$ positive samples (Table 1). This cooling tower also showed the highest frequency of occurrence of Vahlkampfiidae (84.6\%) and of $V$. vermiformis $(11.5 \%)$. There was no correlation between the frequency of occurrence of amoebae and the mode of disinfection, neither concerning the time schedule nor the disinfectants used.

\section{Isolation of FLA and identification of their endosymbionts}

The tap water samples, including the sample from the shower head, were all negative for FLA by culture. Of the cooling water samples, 31 were positive for FLA in the initial cultures and 26 of these could be identified down to the genus level by morphologic characters. We aimed to obtain clonal monoxenic subcultures from all isolates of FLA; however, several cultures were lost due to fungal overgrowth despite treatment with anti-mycotics. Waters collected from CTHospital 1 also contained high numbers of mites and nematodes. Altogether, 16 isolates were successfully brought into monoxenic cultures and subjected to molecular analysis (Table 2). Nine different taxa could be identified by DNA sequencing. CT-Hospital 1 showed the highest amoebal diversity with four different genera (Table 2). Two isolates from CT-Hospital 2 were identified as Naegleria spp., with $100 \%$ sequence homology to one another and with equal sequence identities to N. clarki and N. pagei. Both were shown to grow at $37^{\circ} \mathrm{C}$.

Three amoebal isolates, all from cooling towers, revealed endosymbionts (Table 2). In an Acanthamoeba isolate from CT-Hospital 1, the facultative intracellular bacterium Paracaedibacter acanthamoebae (order Rickettsiales) was detected. A Cochliopodium minus isolate from CT-Hospital 1 contained bacteria belonging to a new genus within the order Legionellales, distinct from the genus Legionella, and an
Acanthamoeba isolate from CT-Hospital 2 contained a novel member of the order Rickettsiales (Tsao et al., in preparation).

\section{Routine screening for bacteria}

Due to the extremely high organic burden in the water samples, 7 of the 66 cooling water samples had to be totally excluded. Despite acid treatment, for further 39 samples (39/59; $66.1 \%$ ) only smaller volumes, i.e. $1-10 \mathrm{ml}$, could be processed for routine screening. Thus, the standard volume of $100 \mathrm{ml}$ could be analysed only from $33.9 \%(20 / 59)$ of the cooling tower samples. Of these, $25 \%(5 / 20)$ were positive for Legionella spp. From the five positive samples, four samples from CT-Hospital 1 were positive for $L$. rubrilucens in increased $(>100-1000 \mathrm{CFU} / 100 \mathrm{ml})$ to highly increased (>1000 CFU/100 ml) concentrations and one sample from CT-Company was positive for $L$. pneumophila (serogroup $2-14)$ in low concentration ( $\leq 100 \mathrm{CFU} / 100 \mathrm{ml})$. The sample taken from the previously Legionella-positive hospital shower head also showed low concentrations (6 CFU/100 ml) of L. pneumophila serogroup 2-14 (Table 2). All other tap water samples investigated were negative. Also, all smaller volumes of water samples investigated remained negative in routine screening.

Of the 28 cooling tower samples analysed by amplicon sequencing, $14(50 \%)$ were positive for at least one Legionella OTU. While CT-Hospital 1 revealed three samples positive for Legionella spp. (21.4\%), from CT-Hospital 2 eleven $(78.6 \%)$ samples were positive. Each hospital cooling tower showed a unique set of Legionella OTUs, with no shared OTUs between the two. In total, we detected six different OTUs within the genus Legionella.

While all tap water samples investigated were negative, $25 \%$ of the cooling tower waters were positive for $P$. aeruginosa. Eleven of these 16 samples showed low 
Table 2 Diversity of microorganisms per sampling site. FLA and Legionella isolated by culture and identified by DNA sequencing. Endosymbionts detected by FISH in isolates of FLA and identified by DNA sequencing

\begin{tabular}{|c|c|c|c|c|}
\hline \multirow[b]{2}{*}{ Taxa } & \multicolumn{2}{|l|}{ FLA } & \multicolumn{2}{|l|}{ Legionella } \\
\hline & No. of isolates & Endosymbionts & Species & No. of isolates \\
\hline \multicolumn{5}{|l|}{ Cooling tower Hospital 1} \\
\hline Acanthamoeba genotype T4 & 3 & $\begin{array}{l}\text { Paracaedibacter } \\
\text { acanthamoebae }\end{array}$ & L. rubrilucens & 4 \\
\hline Cochliopodium minus & 3 & Legionellales & & \\
\hline Stenamoeba sp. & 2 & - & & \\
\hline Thecamoeba sp. & 5 & - & & \\
\hline $\begin{array}{l}\text { Protostelium-like } \\
\text { amoeba }\end{array}$ & 1 & - & & \\
\hline Vahlkampfia avara & 1 & - & & \\
\hline \multicolumn{5}{|l|}{ Cooling tower Hospital 2} \\
\hline Acanthamoeba genotype T4 & 5 & Rickettsiales & & \\
\hline Vahlkampfiidae $^{\mathrm{a}}$ & 1 & - & & \\
\hline Naegleria clarki/pagei ${ }^{\mathrm{b}}$ & 2 & - & & \\
\hline \multicolumn{5}{|l|}{ Cooling tower Company } \\
\hline Acanthamoeba genotype T4 & 1 & - & $\begin{array}{l}\text { L. pneumophila } \\
\text { SG 2-14 }\end{array}$ & 1 \\
\hline Leptomyxa reticulata & 2 & - & & \\
\hline \multicolumn{5}{|l|}{ Shower head } \\
\hline- & - & - & $\begin{array}{l}\text { L. pneumophila } \\
\text { SG 2-14 }\end{array}$ & 1 \\
\hline Total & 26 & 3 & 6 & \\
\hline
\end{tabular}

${ }^{\text {a }}$ Mixed culture of several genera grown at $30^{\circ}$

${ }^{\mathrm{b}}$ Thermophilic bacterial counts (1-100 CFU/100 ml) and 5 samples showed increased concentrations (>100-1000 CFU/100 ml). All samples with increased concentrations were from hospital cooling towers. Altogether, $56.3 \%(9 / 16)$ of the P. aeruginosa-positive samples also were positive for FLA.

Concerning total heterotrophic bacteria, $56.3 \%$ of the samples revealed low bacterial counts $(1-10,000 \mathrm{CFU} / \mathrm{ml})$, while increased numbers $(>10,000-100,000 \mathrm{CFU} / \mathrm{ml})$ were detected in $34.4 \%$ of the samples and $9.4 \%$ showed highly increased concentrations $(>100,000 \mathrm{CFU} / \mathrm{ml})$, all of them from hospital cooling towers. The tap water samples generally showed low concentrations of total bacteria.

\section{Discussion}

With our new screening system for FLA, based on the combination of three group-specific real-time PCRs, we achieved a synchronous, rapid and highly sensitive detection of those amoebae that are most important as hosts for bacteria in water systems under permanent disinfection. It was shown that particularly the waters of hospital cooling towers have a high frequency of occurrence of FLA, even shortly after disinfection and despite having particularly stringent disinfection protocols. Moreover, it was shown that routine screenings for Legionella spp. do not give reliable results for waters with high organic burden.

With the real-time PCR-based screening system for FLA, we achieved a significantly higher sensitivity compared to a previous screening of industrial waters using culture and conventional PCR (Scheikl et al. 2014). As shown previously, culture had a low sensitivity, only $52.7 \%$ of the real-time PCR positive samples being positive; however, the advantage of culture is that basically any viable species of FLA can be found and that isolated amoebae can be screened for intracellular bacteria.

Altogether, $83.3 \%$ of the cooling tower water samples were positive for amoebae suited as hosts for bacterial survival and replication, despite regular disinfection and partly already $1.5 \mathrm{~h}$ after disinfection, independently of the disinfectants used. Interestingly, the two hospital cooling towers had a higher frequency of occurrence of FLA compared to the company cooling tower and, against expectations, the cooling tower from the hospital that had been the source of an Legionella outbreak in 2007 and since then had been dismantled and renewed, showed the highest frequency of occurrence of FLA. This cooling tower also had the highest organic burden and also the highest number of different amoebal taxa. At eight time points, disinfection had been performed shortly (1.5-3.5 h) before the sampling. All these samples still were positive for FLA, even in culture, demonstrating that disinfection had no effect on amoebal viability. From 
these cultures, among others, also one strain of $C$. minus was isolated that carried bacteria belonging to the Legionellales. Moreover, the co-occurrence of C. minus and Legionella rubrilucens was demonstrated in this hospital, CT-Hospital 1. FLA are a natural reservoir for legionellae and particularly open wet cooling towers provide optimal conditions for growth and dissemination of both of these taxa. Acanthamoeba and also Cochliopodium are known to be even stimulated by biocides recommended for cooling towers (Srikanth and Berk 1993). This once more corroborates the known reservoir function of amoebae for potentially pathogenic bacteria (Greub and Raoult 2004). Surprisingly, also vahlkampfiid amoebae were detected in all cooling towers, demonstrating that disinfection did not have a significant impact on even these more sensitive FLA compared to Acanthamoeba spp. (Pagnier et al. 2009; Canals et al. 2015).

Acanthamoeba showed the highest overall frequency of occurrence followed by vahlkampfiid amoebae, a majority of samples being positive for both. Atlan et al. (2012) revealed either Acanthamoeba or Vermamoeba as dominating genera in cooling towers and a predominance of Acanthamoeba was reported from water treatment plants (Magnet et al. 2013), while $V$ vermiformis was found to be the most abundant FLA species in drinking water (Thomas et al. 2008; Wang et al. 2012; Delafont et al. 2013; Pagnier et al. 2015), and in hot water systems (Rohr et al. 1998). In the current study, $V$. vermiformis was absent in tap water and also rarely found in cooling towers (7.6\%). This might be attributed to Vermamoeba's higher sensitivity to biocides compared to Acanthamoeba (Coulon et al. 2010; Fouque et al. 2015). The higher frequency of occurrence of vahlkampfiids compared to a previous study on industrial waters (Scheikl et al. 2014) may be attributed to the higher sensitivity of the real-time PCR, but probably also to the warmer water temperatures. Vahlkampfiids are generally known to occur in cooling towers (Rohr et al. 1998; Canals et al. 2015). In the current study, also two thermophilic Naegleria strains, related to $N$. clarki and N. pagei, were isolated. Although both species are not considered pathogenic, they belong to the same phylogenetic cluster as $N$. australiensis and $N$. italica, which were shown to be pathogenic in animal experiments (De Jonckheere 2014).

Cooling tower waters with their constantly warm temperatures and a weak alkaline $\mathrm{pH}$ provide ideal conditions for Legionella spp., including L. pneumophila (Wadowsky et al. 1985), and also for FLA, including amoebae carrying bacteria (Berk et al. 2006; Huang et al. 2011; Buse et al. 2012). All Legionella-positive samples showed elevated temperatures, i.e. between 26 and $30{ }^{\circ} \mathrm{C}$. The tap waters with temperatures $<12{ }^{\circ} \mathrm{C}$ were all negative for Legionella spp., but the sample from the shower head was positive for L. pneumophila serogroup 2-14, although it had been cleaned and disinfected before. Three cooling tower water samples showed highly increased concentrations of $L$. rubrilucens $(18,000-22,000 \mathrm{CFU} /$ $100 \mathrm{ml}$ ) and one sample increased numbers of $L$. rubrilucens
(600 CFU/100 ml) although disinfected 1 day before sampling. L. rubrilucens always co-occurred with Acanthamoeba or Vahlkampfiidae or both amoebal groups.

Finally, our study indicates that the standard protocol for Legionella routine screening is not suitable for waters from open cooling towers with a high organic burden. For the majority of these samples, only reduced volumes can be investigated, resulting in unreliably low recovery rates for Legionella. In our study, only $7.6 \%$ of all samples were positive for Legionella by culture. In comparison, the ampliconbased screening revealed the presence of Legionella spp. in $50 \%$ of the samples investigated. In fact, the ISO 11731-2 (2004) standard protocol was initially established for waters with low bacterial counts (e.g. tap water), it is however, widely used for Legionella detection also from engineered waters. Non-standard molecular biological methods like CARDFISH reveal higher numbers of Legionella-positive samples and also higher concentrations compared to the standard method (Kirschner et al. 2012). Co-culture with amoebae (Magnet et al. 2015) is another sensitive tool to isolate Legionella and other potentially pathogenic bacteria like chlamydiae, Pseudomonas spp. or mycobacteria from various sampling sources (Collingro et al. 2005; Thomas et al. 2008; Corsaro et al. 2010; Kebbi-Beghdadi and Greub 2014). However, both techniques have not yet been implicated into routine screenings. In the current study, $P$. aeruginosa was generally detected in low concentrations; increased concentrations were only measured at elevated temperatures $\left(27^{\circ} \mathrm{C}\right)$. Increased counts of $P$. aeruginosa and highly increased counts of total bacteria, respectively, were only detected in the hospital cooling towers. The majority of $P$. aeruginosa-positive samples was also positive for FLA, whereby Acanthamoeba always co-occurred with $P$. aeruginosa. Interestingly, all culture-positive samples for Legionella were negative for $P$. aeruginosa. It has been assumed that $P$. aeruginosa inhibits the growth of L. pneumophila (Kimura et al. 2009).

Altogether, our study highlights the need for a regular and regulated screening of cooling towers and for standardized modified screening protocols for these types of waters, possibly also including FLA.

\section{Conclusions}

In conclusion, the newly established real-time PCR-based screening system for amoebae is well-suited for a regular and synchronous screening for various groups of FLA in water samples. It was demonstrated that there is a high frequency of occurrence of amoebae suited as hosts for bacteria in cooling towers, particularly in hospital cooling towers, and that regular disinfection does not affect amoebal survival. Moreover, it was shown that results obtained from 
Legionella routine screenings are not always reliable for water samples with high organic burden.

Acknowledgments Open access funding provided by Medical University of Vienna. We thank the staff of the units Molecular Parasitology and Water Hygiene (Center for Pathophysiology, Infectiology and Immunology, Medical University of Vienna), especially Prof. Regina Sommer and Dr. Peter Hufnagl (AGES) for their help and support. We also want to thank Prof. Michael Kundi from the Institute of Environmental Hygiene (Medical University of Vienna) for critically reading the manuscript and for his advice and Dr. Martin Mrva from the Department of Zoology of the Comenius University in Bratislava for his help with morphological identification.

\section{Compliance with ethical standards}

Ethical standard This study did not include any human/animal material.

Funding information This work was funded by the Austrian Science Fund (FWF, project TRP 209-B20).

Conflict of interest None declared.

Open Access This article is distributed under the terms of the Creative Commons Attribution 4.0 International License (http:// creativecommons.org/licenses/by/4.0/), which permits unrestricted use, distribution, and reproduction in any medium, provided you give appropriate credit to the original author(s) and the source, provide a link to the Creative Commons license, and indicate if changes were made.

\section{References}

Addiss DG, Davis JP, LaVenture M et al (1989) Community-acquired Legionnaires' disease associated with a cooling tower: evidence for longer-distance transport of Legionella pneumophila. Am J Epidemiol 130:557-568

Amann RI, Binder BJ, Olson RJ et al (1990) Combination of 16S rRNAtargeted oligonucleotide probes with flow cytometry for analyzing mixed microbial populations. Appl Env Microbiol 56:1919-1925

Atlan D, Coupat-Goutaland B, Risler A et al (2012) Micriamoeba tesseris nov. gen. nov. sp.: a new taxon of free-living small-sized Amoebae non-permissive to virulent Legionellae. Protist 163:888-902

Behets J, Declerck P, Delaedt Y et al (2007) A duplex real-time PCR assay for the quantitative detection of Naegleria fowleri in water samples. Water Res 41:118-126

Berk SG, Gunderson JH, Newsome AL et al (2006) Occurrence of infected amoebae in cooling towers compared with natural aquatic environments: implications for emerging pathogens. Environ Sci Technol 40:7440-7444

Buse HY, Schoen ME, Ashbolt NJ (2012) Legionellae in engineered systems and use of quantitative microbial risk assessment to predict exposure. Water Res 46:921-933

Canals O, Serrano-Suárez A, Salvadó H et al (2015) Effect of chlorine and temperature on free-living protozoa in operational man-made water systems (cooling towers and hot sanitary water systems) in Catalonia. Environ Sci Pollut Res 22:6610-6618

Cervero-Aragó S, Rodríguez-Martínez S, Canals O et al (2014) Effect of thermal treatment on free-living amoeba inactivation. J Appl Microbiol 116:728-736
Cirillo JD, Falkow S, Tompkins LS, Bermudez LE (1997) Interaction of Mycobacterium avium with environmental amoebae enhances virulence. Infect Immun 65:3759-3767

Cirillo JD, Cirillo SL, Yan L et al (1999) Intracellular growth in Acanthamoeba castellanii affects monocyte entry mechanisms and enhances virulence of Legionella pneumophila. Infect Immun 67:44274434

Collingro A, Poppert S, Heinz E et al (2005) Recovery of an environmental Chlamydia strain from activated sludge by co-cultivation with Acanthamoeba sp. Microbiology 151:301-309

Corsaro D, Michel R, Walochnik J et al (2010) Saccamoeba lacustris, sp. nov. (Amoebozoa: Lobosea: Hartmannellidae), a new lobose amoeba, parasitized by the novel chlamydia "Candidatus Metachlamydia lacustris” (Chlamydiae: Parachlamydiaceae). Eur J Protistol 46:8695

Coulon C, Collignon A, McDonnell G, Thomas V (2010) Resistance of Acanthamoeba cysts to disinfection treatments used in health care settings. J Clin Microbiol 48:2689-2697

Daims H, Brühl A, Amann R et al (1999) The domain-specific probe EUB338 is insufficient for the detection of all bacteria: development and evaluation of a more comprehensive probe set. Syst Appl Microbiol 22:434-444

De Jonckheere JF (2014) What do we know by now about the genus Naegleria? Exp Parasitol 145:S2-S9

Delafont V, Brouke A, Bouchon D et al (2013) Microbiome of free-living amoebae isolated from drinking water. Water Res 47:6958-6965

Dupuy M, Mazoua S, Berne F et al (2011) Efficiency of water disinfectants against Legionella pneumophila and Acanthamoeba. Water Res 45:1087-1094

European Working Group for Legionella Infections (2011) EWGLITechnical-Guidelines for the Investigation, Control and Prevention of Travel Associated Legionnaire's Disease

Fouque E, Héchard Y, Hartemann P et al (2015) Sensitivity of Vermamoeba (Hartmannella) vermiformis cysts to conventional disinfectants and protease. J Water Health 13:302

Freudenmann M, Kurz S, von Baum H et al (2011) Interdisciplinary management of a large Legionella outbreak in Germany (Interdisziplinäres Management eines länderübergreifenden Legionellenausbruchs). Bundesgesundheitsblatt - Gesundheitsforsch - Gesundheitsschutz 54: 1161-1169

García MT, Jones S, Pelaz C, Millar RD, Abu Kwaik Y (2007) Acanthamoeba polyphaga resuscitates viable non-culturable Legionella pneumophila after disinfection. Environ Microbiol 9: 1267-1277

Gast RJ, Fuerst PA, Byers TJ (1994) Discovery of group I introns in the nuclear small subunit ribosomal RNA genes of Acanthamoeba. Nucleic Acids Res 22:592-596

Gast RJ, Ledee DR, Fuerst PA, Byers TJ (1996) Subgenus systematics of Acanthamoeba: four nuclear 18S rDNA sequence types. J Eukaryot Microbiol 43:498-504

Geisen S, Fiore-Donno AM, Walochnik J, Bonkowski M (2014) Acanthamoeba everywhere: high diversity of Acanthamoeba in soils. Parasitol Res 113:3151-3158

Greub G, Raoult D (2004) Microorganisms resistant to free-living amoebae. Clin Microbiol Rev 17:413-433

Herbold CW, Pelikan C, Kuzyk O et al (2015) A flexible and economical barcoding approach for highly multiplexed amplicon sequencing of diverse target genes. Front Microbiol 6:1-8

Herlemann DP, Labrenz M, Jürgens K et al (2011) Transitions in bacterial communities along the $2000 \mathrm{~km}$ salinity gradient of the Baltic Sea. ISME J 5:1571-1579

Huang S-W, Hsu B-M, Chen N-H et al (2011) Isolation and identification of Legionella and their host amoebae from weak alkaline carbonate spring water using a culture method combined with PCR. Parasitol Res 109:1233-1241 
Hugosson A, Hjorth M, Bernander S et al (2007) A community outbreak of Legionnaires' disease from an industrial cooling tower: assessment of clinical features and diagnostic procedures. Scand J Infect Dis 39:217-224

Hussong D, Colwell RR, O'Brien M et al (1987) Viable Legionella pneumophila not detectable by culture on agar media. Bio/ Technology 5:947-950

Hwang MG, Katayama H, Ohgaki S (2006) Effect of intracellular resuscitation of Legionella pneumophila in Acanthamoeba polyphage cells on the antimicrobial properties of silver and copper. Environ Sci Technol 40:7434-7439

ISO 11731-2 (2004) (International Organization for Standardization) Water quality - detection and enumeration of Legionella - Part 2: direct membrane filtration method for waters with low bacterial counts (ÖNORM EN ISO 11731-2:2008)

ISO 16266 (2008) (International Organization for Standardization) Water quality-detection and enumeration of Pseudomonas aeruginosa - Method by membrane filtration (ÖNORM EN ISO 16266:2008)

ISO 6222 (1999) (International Organization for Standardization) Water quality - enumeration of culturable microorganisms - colony count by inoculation in a nutrient agar culture medium (ÖNORM EN ISO 6222:1999)

Kebbi-Beghdadi C, Greub G (2014) Importance of amoebae as a tool to isolate amoeba-resisting microorganisms and for their ecology and evolution: the Chlamydia paradigm. Environ Microbiol Rep 6:309324

Kimura S, Tateda K, Ishii Y et al (2009) Pseudomonas aeruginosa Las quorum sensing autoinducer suppresses growth and biofilm production in Legionella species. Microbiology 155:1934-1939

Kirschner A, Rameder A, Schrammel B et al (2012) Development of a new CARD-FISH protocol for quantification of Legionella pneumophila and its application in two hospital cooling towers. $\mathrm{J}$ Appl Microbiol 112:1244-1256

La Scola B, Raoult D (2001) Survival of Coxiella burnetii within freeliving amoeba Acanthamoeba castellanii. Clin Microbiol Infect 7: 75-79

Lane DJ (1991) 16S/23S rRNA sequencing. In: Nucleic acid techniques in bacterial systematics. Stackebrandt E, Goodfellow M (eds.), John Wiley and Sons, New York, NY, 115-175

Magnet A, Fenoy S, Galván AL et al (2013) A year long study of the presence of free living amoeba in Spain. Water Res 47: 6966-6972

Magnet A, Peralta RHS, Gomes TS, Izquierdo F, Fernandez-Vadillo C, Galvan AL, Pozuelo MJ, Pelaz C, Fenoy S, Del Áquila C (2015) Vectorial role of Acanthamoeba in Legionella propagation in water for human use. Sci Total Environ 505:889-895

Nguyen TMN, Ilef D, Jarraud S et al (2006) A community-wide outbreak of Legionnaires disease linked to industrial cooling towers - how far can contaminated aerosols spread? J Infect Dis 193:102-11

Nicholas KB, Nicholas HB, Deerfield DW (1997) GeneDoc: analysis and visualization of genetic variation. EMBnet News 4:14

Ohno A, Kato N, Yamada K, Yamaguchi K (2003) Factors influencing survival of Legionella pneumophila serotype 1 in hot spring water and tap water. Appl Environ Microbiol 69:2540 2547

ÖNORM B 5020:2013 Austrian Standards Institute (2013) Requirements for microbiological water quality in evaporative recooling plants

Page FC (1991) Nackte Rhizopoda und Heliozoea. In: Matthes (ed) Protozoenfauna, 2nd edn. Gustav Fischer Verlag, Stuttgart, pp 3170

Pagnier I, Merchat M, La Scola B (2009) Potentially pathogenic amoebaassociated microorganisms in cooling towers and their control. Future Microbiol 4:615-629
Pagnier I, Valles C, Raoult D, La Scola B (2015) Isolation of Vermamoeba vermiformis and associated bacteria in hospital water. Microb Pathog 80:14-20

Quast C, Pruesse E, Yilmaz P et al (2013) The SILVA ribosomal RNA gene database project: improved data processing and web-based tools. Nucleic Acids Res 41:D590-D596

Qvarnstrom Y, Visvesvara GS, Sriram R, da Silva AJ (2006) Multiplex real-time PCR assay for simultaneous detection of Acanthamoeba spp., Balamuthia mandrillaris, and Naegleria fowleri. J Clin Microbiol 44:3589-3595

Retana-Moreira L, Abrahams-Sandí E, Cabello-Vílchez AM et al (2014) Isolation and molecular characterization of Acanthamoeba and Balamuthia mandrillaris from combination shower units in Costa Rica. Parasitol Res 113:4117-4122

Robertson P, Abdelhady H, Garduno RA (2014) The many forms of a pleomorphic bacterial pathogen - the developmental network of Legionella pneumophila. Front Microbiol 5:1-20

Rohr U, Weber S, Michel R et al (1998) Comparison of free-living amoebae in hot water systems of hospitals with isolates from moist sanitary areas by identifying genera and determining temperature tolerance. Appl Environ Microbiol 64:1822-1824

Rowbotham TJ (1980) Preliminary report on the pathogenicity of Legionella pneumophila for freshwater and soil amoebae. J Clin Pathol 33:1179-1183

Sala Ferré MR, Arias C, Oliva JM et al (2009) A community outbreak of Legionnaires' disease associated with a cooling tower in Vic and Gurb, Catalonia (Spain) in 2005. Eur J Clin Microbiol Infect Dis 28:153-159

Scheikl U, Sommer R, Kirschner A et al (2014) Free-living amoebae (FLA) co-occurring with legionellae in industrial waters. Eur J Protistol 50:422-429

Schloss PD, Westcott SL, Ryabin T et al (2009) Introducing mothur: open-source, platform-independent, community-supported software for describing and comparing microbial communities. Appl Environ Microbiol 75:7537-7541

Schroeder JM, Booton GC, Hay J et al (2001) Use of subgenic 18S ribosomal DNA PCR and sequencing for genus and genotype identification of acanthamoebae from humans with keratitis and from sewage sludge. J Clin Microbiol 39:1903-1911

Siddiqui R, Khan NA (2012) War of the microbial worlds: who is the beneficiary in Acanthamoeba-bacterial interactions? Exp Parasitol 130:311-313

Smirnov A, Brown S (2004) Guide to the methods of study and identification of soil gymnamoebae. Protistology 3:148-190

Smirnov AV, Chao E, Nassonova ES, Cavalier-Smith T (2011) A revised classification of naked lobose amoebae (Amoebozoa: Lobosa). Protist 162:545-570

Srikanth S, Berk SG (1993) Stimulatory effect of cooling tower biocides on amoebae. Appl Environ Microbiol 59:3245-3249

Steinert M, Emödy L, Amann R, Hacker J (1997) Resuscitation of viable but nonculturable Legionella pneumophila Philadelphia JR32 by Acanthamoeba castellanii. Appl Environ Microbiol 63: 2047-2053

Thomas V, Loret J-F, Jousset M, Greub G (2008) Biodiversity of amoebae and amoebae-resisting bacteria in a drinking water treatment plant. Environ Microbiol 10:2728-2745

Thompson JD, Gibson TJ, Plewniak F et al (1997) The CLUSTAL X windows interface: flexible strategies for multiple sequence alignment aided by quality analysis tools. Nucleic Acids Res 25:48764882

Wadowsky RM, Wolford R, McNamara AM, Yee RB (1985) Effect of temperature, $\mathrm{pH}$, and oxygen level on the multiplication of naturally occurring Legionella pneumophila in potable water. Appl Environ Microbiol 49:1197-1205

Walochnik J, Picher O, Aspöck C, Ullmann M, Sommer R, Aspöck H (1999) Interactions of "Limax amoebae" and gram-negative 
bacteria: experimental studies and review of current problems. Tokai J Exp Clin Med 23(6):273-278

Walochnik J, Obwaller A, Aspöck H (2000) Correlations between morphological, molecular biological, and physiological characteristics in clinical and nonclinical isolates of Acanthamoeba spp. Appl Environ Microbiol 66:4408-4413

Walochnik J, Michel R, Aspöck H (2004) A molecular biological approach to the phylogenetic position of the genus Hyperamoeba. $\mathrm{J}$ Eukaryot Microbiol 51:433-440

Walser SM, Gerstner DG, Brenner B et al (2014) Assessing the environmental health relevance of cooling towers - a systematic review of legionellosis outbreaks. Int J Hyg Environ Health 217: $145-154$
Wang H, Edwards M, Falkinham JO, Pruden A (2012) Molecular survey of the occurrence of Legionella spp., Mycobacterium spp., Pseudomonas aeruginosa, and amoeba hosts in two chloraminated drinking water distribution systems. Appl Environ Microbiol 78: 6285-6294. doi:10.1128/AEM.01492-12

Wewalka G (2013) Requirements for the microbiological water quality in evaporative cooling plants (Anforderungen an die mikrobiologische Wasserqualität in Verdunstungsrückkühlanlagen) - new ÖNORM B 5020

Winiecka-Krusnell J, Linder E (2001) Bacterial infections of free-living amoebae. Res Microbiol 152:613-619 